\title{
Weed Control in Parsley 1
}

\author{
William M. Stall ${ }^{2}$
}

Parsley is placed in the "leafy greens" EPA group due to its closeness to lettuce and spinach for residues. Check Weed Control in Leafy Vegetables at http://edis.ifas.ufl.edu/wg031 for possibly more labels. Bensulide may be applied to parsley preplant incorporated or preemergence on mineral soils.

Linuron is labeled for weed control in parsley (Table 1). The label for linuron is relatively new and the material should be used on a trial basis until experience is gained as to rates and timing at specific locations. Linuron may be applied as a postemergence application over parsley in muck soils only.

\section{Read and follow all label directions.}

1. This document is HS952, one of a series of the Horticultural Sciences Department, Florida Cooperative Extension Service, Institute of Food and Agricultural Sciences, University of Florida. Publication date: August 2003. Formerly combined with Weed Control in Carrot. Please visit the EDIS Website at http://edis.ifas.ufl.edu.

2. William M. Stall, professor, Horticultural Sciences Department, Cooperative Extension Service, Institute of Food and Agricultural Sciences, University of Florida, Gainesville, 32611

The use of trade names in this publication is solely for the purpose of providing specific information. It is not a guarantee or warranty of the product named, and does not signify that they are approved to the exclusion of others of suitable composition.

The Institute of Food and Agricultural Sciences is an equal opportunity/affirmative action employer authorized to provide research, educational information and other services only to individuals and institutions that function without regard to race, color, sex, age, handicap, or national origin. For information on obtaining other extension publications, contact your county Cooperative Extension Service office. Florida Cooperative Extension Service/Institute of Food and Agricultural Sciences/University of Florida/Christine Taylor Waddill, Dean. 
Table 1. Chemical Weed controls: Parsley.

\begin{tabular}{|c|c|c|c|c|}
\hline \multirow[t]{2}{*}{ Herbicide } & \multirow[t]{2}{*}{ Labeled crops } & \multirow{2}{*}{$\begin{array}{l}\text { Time of application to } \\
\text { crops }\end{array}$} & \multicolumn{2}{|c|}{ Rate (Ibs. Al./Acre) } \\
\hline & & & Mineral & Muck \\
\hline $\begin{array}{l}\text { Bensulide } \\
\text { (Prefar 4E) }\end{array}$ & Parsley & $\begin{array}{l}\text { Preplant, } \\
\text { Preemergence }\end{array}$ & $5-6$ & --- \\
\hline \multicolumn{5}{|c|}{$\begin{array}{l}\text { Remarks: May be applied preplant and incorporated with power driven cultivations or may be incorporated with } \\
\text { irrigation. }\end{array}$} \\
\hline Linuron (Lorox DF) & Parsley & $\begin{array}{l}\text { Preemergence } \\
\text { Postemergence }\end{array}$ & $\begin{array}{l}0.75 \\
\mathrm{NL}\end{array}$ & $\begin{array}{l}0.75-1.5 \\
0.5\end{array}$ \\
\hline \multicolumn{5}{|c|}{$\begin{array}{l}\text { Remarks: Apply a single broadcast application in mineral and muck soils after planting but before plant } \\
\text { emergence. In muck soils only, an additional application may be made after parsley emergence when weeds are } \\
\text { in } 1 \text { to } 3 \text { leaf stage. Do not apply within } 30 \text { days of harvest. }\end{array}$} \\
\hline $\begin{array}{l}\text { Pelargonic Acid } \\
\text { (Scythe) }\end{array}$ & Parsley & $\begin{array}{l}\text { Preplant, Preemergence, } \\
\text { Directed-shielded }\end{array}$ & $3-10 \% \mathrm{v} / \mathrm{v}$ & $3-10 \% v / v$ \\
\hline \multicolumn{5}{|c|}{$\begin{array}{l}\text { Remarks: Product is a contact, non-selective, foliar applied herbicide. There is no residual control. May be tank } \\
\text { mixed with soil residual compounds. Consult label for rates and other information. }\end{array}$} \\
\hline $\begin{array}{l}\text { Prometryne } \\
\text { (Caparol 4L) }\end{array}$ & Parsley & Postemergence & $0.25-.5$ & $0.25-.5$ \\
\hline \multicolumn{5}{|c|}{$\begin{array}{l}\text { Remarks: Caparol } 4 \mathrm{~L} \text { may be applied postemergent as a broadcast application at } .5-1 \text { pint/A to direct seeded } \\
\text { parsley or dill. Applications may be made no closer then } 30 \text { days prior to harvest. Applications must be made in a } \\
\text { minimum of } 20 \mathrm{gpa} \text {. A maximum of } 1 \mathrm{lb} \text { a. } \mathrm{i} / \mathrm{A}(2 \mathrm{pts} / \mathrm{A}) \text { of Caparol } 4 \mathrm{~L} \text { may be applied per growing season. Crops } \\
\text { treated may be sold for fresh market only. This is a third party registration. Authorization and waiver agreements } \\
\text { must be obtained from TPR, Inc. prior to use. The use of the product may result in stunting and delayed maturity. } \\
\text { Climatic conditions during the growing season will affect efficacy and phytotoxicity. }\end{array}$} \\
\hline $\begin{array}{l}\text { Sethoxydim } \\
\text { (Poast) }\end{array}$ & Parsley & Postemergence & $0.188-0.28$ & $0.188-0.47$ \\
\hline \multicolumn{5}{|c|}{$\begin{array}{l}\text { Remarks: Controls actively growing grass weeds. A maximum rate of } 2.5 \text { pints product may be made per } \\
\text { application. A total of } 5 \text { pints product may be applied per season. There is a } 30 \text { day PHI (pre harvest interval). } \\
\text { Consult label for rates for grass species and growth stages for best control. }\end{array}$} \\
\hline
\end{tabular}

